\title{
An Unusual and Complex Congenital Heart Disease in a Patient with a Ruptured Cerebral Aneurysm
}

\author{
Rüptüre Serebral Anevrizma Bulunan Bir Hastada Alışlmadlk ve \\ Karmaşık Doğumsal Kalp Hastalı̆̆ı
}

Po-Yuan CHEN, Han-Jung CHEN, Kang LU

E-Da Hospital, I-Shou University, Department of Neurosurgery, Kaobsiung, Taiwan

Corresponding Author: Kang LU / E-mail: u8801051@gmail.com

\begin{abstract}
A 38-year-old woman had complex, congenital heart anomalies, including double-outlet right ventricle with mitral atresia, severe left ventricle hypoplasia, atrial septal defect, and severe pulmonary stenosis, for which she had not received appropriate treatment. She presented to our institution with an intense sudden-onset headache that had initiated while sleeping. Brain computed tomography indicated the presence of spontaneous subarachnoid hemorrhage. Cerebral angiography revealed a left middle cerebral artery aneurysm. Two days later, she underwent a craniotomy for aneurysm clipping. According to the pathological analysis, culture, and clinical presentation, the aneurysm was not mycotic. The patient regained consciousness after a few days postoperatively.

Despite the complex and rare congenital heart disease, it is especially notable that the patient survived 38 years without treatment and later had a ruptured cerebral aneurysm that was successfully managed operatively. Our literature review indicated that some congenital heart diseases such as aortic coarctation may correlate with the presence of intracranial aneurysms. Our case is novel because there are no similar cases of complex congenital heart disease combined with a ruptured intracranial aneurysm successfully resolved operatively. We believe that this case would help clinicians deal with such complicated cases of congenital heart disease combined with intracranial aneurysms.
\end{abstract}

KEYWORDS: Congenital heart disease, Double-outlet right ventricle, Aneurysm

öz

Otuz sekiz yaşında bir kadında mitral atrezi, şiddetli sol ventrikül hipoplazisi, atriyal septal defekt ve şiddetli pulmoner stenozla birlikte çift çıkışlı sağ ventrikül dahil konjenital kalp anomalileri vardı ve bunlar için uygun tedavi almamıştı. Kurumumuza uyurken aniden başlayan şiddetli başağıısı ile geldi. Bilgisayarlı beyin tomografisi spontan subaraknoid kanama varlığını işaret etti. Serebral anjiyografi bir sol orta serebral arter anevrizmasını ortaya koydu. İki gün sonra anevrizmayı kliplemek için kraniyotomi yapıldı. Patoloji analizi, kültür ve klinik sunuma göre anevrizma mikotik değildi. Hastanın bilinci ameliyattan birkaç gün sonra açıldı.

Karmaşık ve alışılmadık konjenital kalp hastalığına rağmen hastanın tedavi almadan 38 yıl yaşaması ve daha sonra operatif olarak başarıyla tedavi edilen bir rüptüre serebral anevrizması olması özellikle ilginçtir. Literatür derlememiz aort koarktasyonu gibi bazı konjenital kalp hastalıklarının intrakraniyal anevrizma varlığıyla ilişkili olabileceğine işaret etti. Olgumuz ameliyatla başarıyla tedavi edilen rüptüre bir intrakraniyal anevrizma ile kombine benzer bir karmaşık konjenital kalp hastalığı olgusu literatürde olmadığı için ilginçtir. Bu olgunun klinisyenlerin intrakraniyal anevrizmalarla kombine olan karmaşık konjenital kalp hastalığı olguları gibi durumlarla başa çıkmasına yardımcı olacağına inanıyoruz.

ANAHTAR SÖZCÜKLER: Konjenital kalp hastalığı, Çift çıkışlı sağ ventrikül, Anevrizma

\section{INTRODUCTION}

The incidence of fatalities due to congenital heart diseases is decreasing owing to improvements of prenatal examinations. Congenital heart diseases associated with intracranial aneurysms have seldom been reported. We report a ruptured intracranial aneurysm in a 38-year-old woman with a complex congenital heart disease.

\section{CASE REPORT}

A 38-year-old woman had been experiencing various symptoms but had not been diagnosed with a rare congenital heart disease because of economic limitations. She constantly experienced dyspnea after light activities. She had limited outdoor activities and was mostly homebound, until presentation to our hospital.

She presented to our institution owing to sudden-onset headache induced while sleeping. Brain computed tomography indicated the presence of a spontaneous subarachnoid hemorrhage. Cerebral angiography revealed a left middle cerebral artery aneurysm (Figure 1). After admission to the intensive care unit, we found an obvious heart murmur and clubbing fingers on physical examination. The oximeter showed a constant $\mathrm{O}_{2}$ saturation of approximately $80 \%$. Complex cardiac anomalies were identified and diagnosed via cardiac echocardiography and chest computed tomography (Figure 2A-C). The anomalies included double-outlet right ventricle (DORV), 
mitral atresia, severe left ventricle hypoplasia, atrial septal defect, and severe pulmonary stenosis.

Owing to concerns of aneurysm rerupture, she underwent craniotomy for aneurysm clipping two days after admission because of the complex congenital heart disease and high operative risk. The perioperative course was uneventful. $\mathrm{O}_{2}$ saturation was maintained at approximately $85 \%$. The aneurysm was clipped and excised without any difficulty and was subsequently sent for culture and pathologic examination.

During the postoperative period, the patient presented a seizure that was controlled after the administration of anticonvulsant medication. The patient regained consciousness after a few days postoperatively. According to

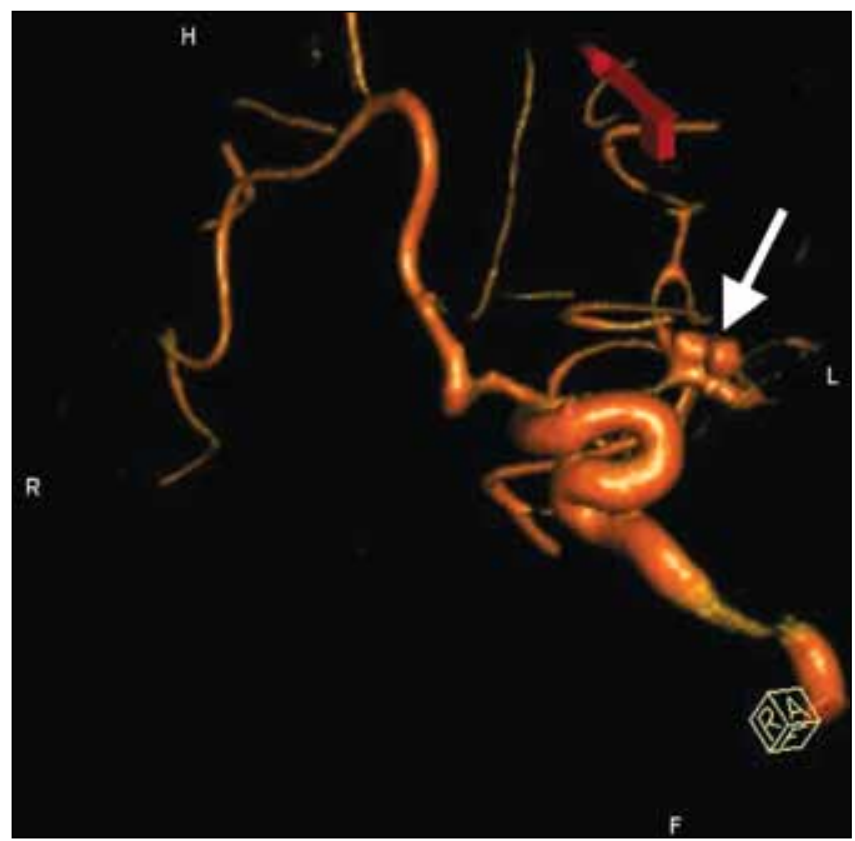

Figure 1: Angiography showing left middle cerebral artery aneurysm (white arrow). the pathological analysis, culture, and clinical presentation, the aneurysm was not considered mycotic. At hospital discharge, general weakness and limited ambulation were still noted. At 1-month follow-up, she could walk upstairs without any assistance. Intermittent somnolence and some degree of short-term memory loss persisted after 1.5 years of follow-up. We suggested she should receive appropriate treatment for the cardiac disease, but she refused and continued to take medication for preventing heart failure.

\section{DISCUSSION}

Our literature review indicated that cases of congenital heart diseases combined with intracranial aneurysm have seldom been reported. Some studies have reported an association between congenital heart diseases and the occurrence of mycotic aneurysms (bacterial intracranial aneurysm) caused by bacterial emboli that directly reach the cerebral circulation and reimplant on the arterial walls (20).

Certain inherited diseases, such as Alagille syndrome (19), Loeys-Dietz syndrome (8,15), Aarskog-Scott syndrome (6), Marfan syndrome $(10,11)$, and Ehlers-Danlos syndrome (14, 16), in which patients present with cardiac and extracardiac anomalies, may frequently be associated with intracranial aneurysms. However, our case had just pure cardiac anomalies without associated extracardiac anomalies. Our case also could not be found to have any inherited diseases.

Intracranial aneurysms were also frequently found in conjunction with aortic coarctation. The pathophysiological basis of this association is still unknown. It is known that the myocardial and cervicocephalic arteries and the aortic arch originate from the neural ridge tissue, also called the neural crest. Thus, a developmental error originating from the neural ridge can cause both cardiac abnormalities and intracranial aneurysms (17). However, the presence of aortic coarctation alone was found to increase the incidence of intracranial aneurysms $(1,3,7,17)$. Another congenital heart condition, the presence of a bicuspid aortic valve, which is often
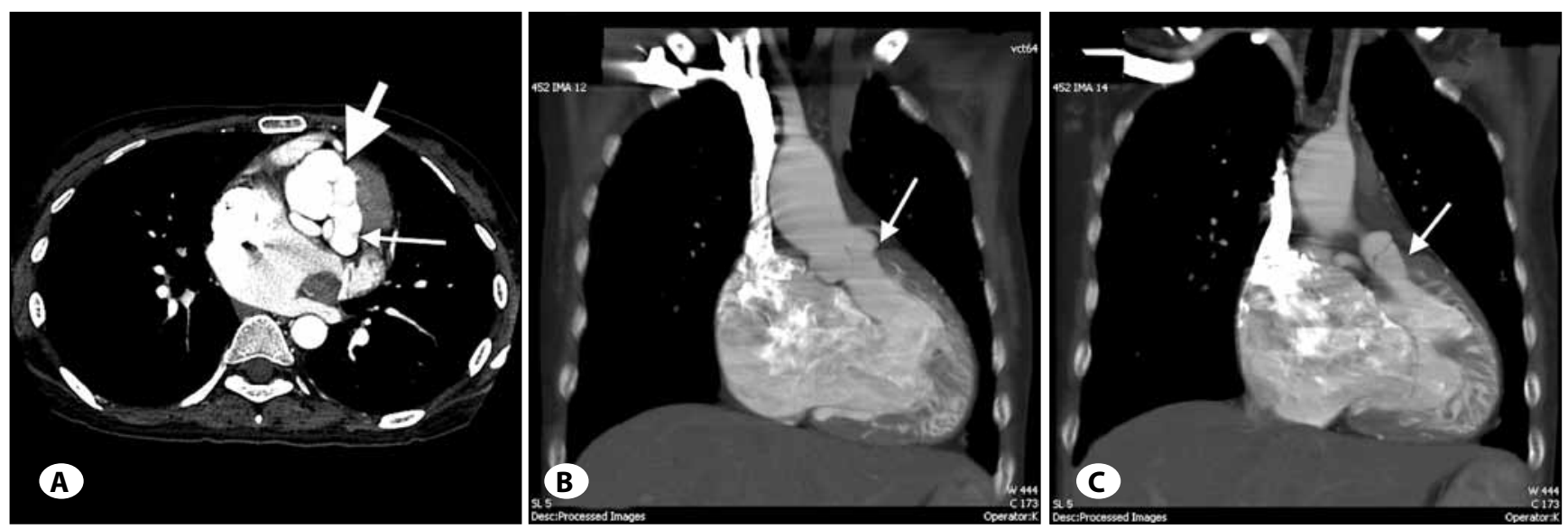

Figure 2: Chest computed tomography showing an enlarged right atrium and ventricle and a double-outlet right ventricle: A) Abnormal position of the aortic root (thick arrow) and pulmonary trunk (thin arrow), axial view; B) Aortic root arising from the right ventricle (arrow), coronal view; C) Pulmonary trunk arising from the right ventricle (arrow), coronal view. 
Table I: Congenital Heart Disease Associated with Intracranial Aneurysms

\begin{tabular}{|c|c|c|c|c|}
\hline Patient number & Age $(\mathrm{a} / \mathbf{b})^{+}$and sex & Congenital heart disease & Intracranial aneurysm type & Reference \\
\hline 1 & $(0 / 17) \mathrm{F}$ & Persistent truncus arteriosus & ACoA aneurysm & 17 \\
\hline 2 & $(0 / 24) \mathrm{F}$ & Tricuspid atresia & ICA aneurysm & 17 \\
\hline 3 & $(0 / 26) \mathrm{M}$ & Transposition of great arteries & MCA aneurysm & 17 \\
\hline 5 & $(6 / 17) \mathrm{F}$ & Pulmonary artery stenosis & BA aneurysm & 12 \\
\hline 6 (Our case) & $(3 / 10) \mathrm{F}$ & Transposition of great arteries & Multiple aneurysms \\
\hline
\end{tabular}

+: Age in years; (a/b): a for the age at diagnosis of congenital heart disease, $b$ for the age at diagnosis of intracranial aneurysm, $\boldsymbol{F}:$ female, $\boldsymbol{M}:$ male, DORV: double outlet right ventricle, ACoA: anterior communicating artery, ICA: internal carotid artery, MCA: middle cerebral artery, BA: basilar artery

associated with aortic coarctation, has also been reported in association with an increased incidence of intracranial aneurysms. Intracranial aneurysms associated with bicuspid aortic valve seemed to be caused by the same hypothesized mechanism as in aortic coarctation $(9,18)$. Moreover, bicuspid aortic valve is also classified as an inherited connective tissue disease, such as Marfan syndrome and Ehlers-Danlos syndrome (2), which may also be associated with intracranial aneurysms. Other congenital heart diseases have not been proven to be associated with intracranial aneurysms.

Gene mutations have also been considered as possible reasons of congenital heart conditions. Filamin A mutation was thought to be associated with periventricular heterotopia, aneurysms, and cardiac defects (5). Although our patient had an aneurysm and a complex congenital heart disease, no periventricular heterotopia was noted.

Except for infective aneurysms, aortic coarctation, and certain inherited diseases, congenital heart diseases have been seldom reported to be associated with non-infective intracranial aneurysms. Table I presents all reported cases of congenital heart diseases that were associated with intracranial aneurysms but not with aortic coarctation, bicuspid aortic valve, or inherited diseases $(12,17)$. However, to our knowledge, no case resembling the complex congenital condition of our patient with an intracranial aneurysm rupture has been reported.

We have attempted to explain the possible underlying mechanism in our case that presented with a cerebral aneurysm. DORV is a rare condition, affecting $1-1.5 \%$ of patients with congenital heart diseases (4). It may occur as an isolated defect, combined with other cardiac anomalies or even with some extracardiac anomalies. In our case, the patient presented a DORV together with multiple cardiac anomalies but no extracardiac anomalies. A study has shown that trisomies 13 and 18 and deletion $22 q 11$ increase the risk of DORV (13), although our patient refused to undergo chromosomal studies. Owing to the diversity of DORV, several distinct pathogenetic mechanisms for DORV have been postulated, including impairment of neural crest derivative migration and impairment of normal cardiac situs and looping (13). An error during neural crest development can also cause cervicocephalic artery anomalies. Thus, it is reasonable that patients with DORV with multiple cardiac anomalies to have an intracranial aneurysm.

In most cases of congenital heart disease combined with aneurysms, it is unclear whether the congenital heart disease or unruptured intracranial aneurysm should be treated first. In our case, this was not a concern because the aneurysm had ruptured; thus, its treatment was prioritized.

\section{CONCLUSIONS}

Based on a literature review, we found that some congenital heart diseases, e.g., aortic coarctation, may be correlated with the presence of intracranial aneurysms. This case is important because of two reasons. First, there have been no reported cases of congenital heart diseases similar to the present case in terms of complexity and combination with a ruptured intracranial aneurysm. Second, despite the complexity and rarity of this congenital heart disease, the ruptured cerebral aneurysm could still be successfully resolved operatively under intensive intraoperative anesthesia and close postoperative care. Thus, we believe that this case would help clinicians deal with such complicated cases of congenital heart disease combined with intracranial aneurysms.

\section{REFERENCES}

1. Bagdure D, Bartakian S, Kaufman J: Coarctation of aorta and vein of Galen aneurysmal malformation in a neonate. Curr Opin Pediatr 23: 249-252, 2011

2. Baxter BT: Heritable diseases of the blood vessels. Cardiovasc Pathol 14(4): 185-188, 2005

3. Cook SC, Hickey J, Maul TM, Zumberge N, Krieger EV, Valente AM, Zaidi AN, Daniels CJ: Assessment of the cerebral circulation in adults with coarctation of the aorta. Congenit Heart Dis 8: 289-295, 2013

4. Demir MT, Amasyali $\mathrm{Y}$, Kopuz C, Aydin ME, Corumlu U: The double outlet right ventricle with additional cardiac malformations: An anatomic and echocardiographic study. Folia Morphol (Warsz) 68(2): 104-108, 2009

5. de Wit MC, Kros JM, Halley DJ, de Coo IF, Verdijk R, Jacobs BC, Mancini GM: Filamin A mutation, a common cause for periventricular heterotopia, aneurysms and cardiac defects. J Neurol Neurosurg Psychiatry 80:426-428, 2009 
6. Diluna $\mathrm{ML}$, Amankulor $\mathrm{NM}$, Johnson $\mathrm{MH}$, Gunel $\mathrm{M}$ : Cerebrovascular disease associated with Aarskog-Scott syndrome. Neuroradiology 49(5): 457-461, 2007

7. Hudaoglu O, Kurul S, Cakmakci H, Men S, Yis U, Dirik E: Aorta coarctation presenting with intracranial aneurysm rupture. J Paediatr Child Health 42: 477-479, 2006

8. Hughes BD, Powers CJ, Zomorodi AR: Clipping of a cerebral aneurysm in a patient with Loeys-Dietz syndrome: Case report. Neurosurgery 69(3): E746-55; discussion E55, 2011

9. Kappetein $A P$, Gittenberger-de Groot $A C$, Zwinderman $A H$, Rohmer J, Poelmann RE, Huysmans HA: The neural crest as a possible pathogenetic factor in coarctation of the aorta andbicuspid aortic valve. J Thorac Cardiovasc Surg 102(6): 830-836, 1991

10. Kubo Y, Ogasawara K, Kurose A, Kakino S, Tomitsuka N, Ogawa A: Ruptured cerebral fusiform aneurysm with mucopolysaccharide deposits in the tunica media in a patient with Marfan syndrome. J Neurosurg 110(3): 518-520, 2009

11. Maski KP, Sengupta S, Silvera M, Rivkin MJ: Intracranial artery dissection in an adolescent with Marfan syndrome. Pediatr Neurol 45(1): 39-41, 2011

12. Muzumdar DP, Sateesh M, Goel A: Multiple intracranial aneurysms in a child with congenital cyanotic heart disease. Pediatr Neurosurg 42(6): 368-373, 2006

13. Obler D, Juraszek AL, Smoot LB, Natowicz MR: Double outlet right ventricle: Aetiologies and associations. J Med Genet 45(8): 481-497, 2008
14. Perrin JM, Turowski B, Steiger HJ, Hänggi D: Double-barrel extracranial-intracranial bypass surgery followed by endovascular carotid artery occlusion in a patient with an extracranial giant internal carotid arteryaneurysm due to Ehlers-Danlos syndrome. J Neurointerv Surg 5(6): e40, 2013

15. Rahme RJ, Adel JG, Bendok BR, Bebawy JF, Gupta DK, Batjer $\mathrm{HH}$ : Association of intracranial aneurysm and Loeys-Dietz syndrome: Case illustration, management, and literature review. Neurosurgery 69(2): E488-92; discussion E492-493, 2011

16. Schievink WI, Link MJ, Piepgras DG, Spetzler RF: Intracranial aneurysm surgery in Ehlers-Danlos syndrome Type IV. Neurosurgery 51(3): 607-611; discussion 611-613, 2002

17. Schievink WI, Mokri B, Piepgras DG, Gittenberger-de Groot AC: Intracranial aneurysms and cervicocephalic arterial dissections associated with congenital heart disease. Neurosurgery 39: 685-689; discussion 689-690, 1996

18. Schievink WI, Raissi SS, Maya MM, Velebir A: Screening for intracranial aneurysms in patients with bicuspid aortic valve. Neurology 74(18): 1430-1433, 2010

19. Schlosser HG, Kerner T, Woiciechowsky C, Benndorf G: Multiple cerebral aneurysms and subarachnoid hemorrhage in a patient with Alagille syndrome. AJNR Am J Neuroradiol 25(8):1366-1367, 2004

20. Takeshita M, Kagawa M, Kubo O, Yato S, Satoh K, Ujiie H, Kasuya $\mathrm{H}$, Izawa M: Clinicopathological study of bacterial intracranial aneurysms. Neurol Med Chir (Tokyo) 31: 508-513, 1991 